\title{
Potential eolian dust contribution to accumulation of selected heavy metals and rare earth elements in the aboveground biomass of Tamarix spp. from saline soils in Kazakhstan
}

\author{
Małgorzata Suska-Malawska (iD • Marcin Sulwiński • \\ Mateusz Wilk • Azimbay Otarov • Monika Mętrak
}

Received: 13 February 2018 / Accepted: 20 December 2018 / Published online: 9 January 2019

(C) The Author(s) 2019

\begin{abstract}
In arid and semi-arid zones, atmospheric dust of different origins influences soil chemistry and plant biomass composition. Thus, studies on plant accumulation of heavy metals and rare earth elements (RREs) should include some assessments of potential eolian deposition. Here, we proposed the use of fractionation of metals in soils as an indirect method to assess potential atmospheric dust input to metal content in plant biomass. Our research was performed on individuals of Tamarix spp. growing on saline automorphic and hydromorphic soils in Kazakhstan. Studied soils could be, in general, classified as polluted, especially in industrial areas of Karaganda and Chromtau. However, concentrations of heavy metals and RREs in biomass remained low, as most of the studied elements were present in plant-inaccessible forms. Nevertheless, we recorded a high accumulation of $\mathrm{Cd}$ in biomass (70\% of this element present in soils as plantinaccessible fractions), which indicates the impact of Cd atmospheric deposition.
\end{abstract}

M. Suska-Malawska $(\bowtie) \cdot$ M. Sulwiński $\cdot$ M. Wilk •

M. Mętrak

Faculty of Biology, Biological and Chemical Research Centre, University of Warsaw, Warsaw, Poland

e-mail: malma@biol.uw.edu.pl

A. Otarov

Kazakh Institute of Soil Science and Agrochemistry, Almaty, Kazakhstan
Keywords Heavy metals $\cdot$ REEs $\cdot$ Soil $\cdot$ Dust pollution $\cdot$ Tamarix spp

\section{Introduction}

Central Asia is a vast area extending from the Caspian Sea to the western borders of China and characterized by highly differentiated landscapes, including high mountains (Tien Shan, Pamir, Altai), excessive desserts, occupying c.a. $60 \%$ of this region (Gobi, Karakum, Kyzylkum), and treeless grassy steppes. Developed under arid and semi-arid continental climate, saline soils are dominating in this region, covering over $20 \%$ of its desserts and steppes. Automorphic saline soils of Central Asian desserts and semi-deserts are established mostly on parent rocks formed from salt-bearing marine deposits of the Cretaceous period and/or salt-bearing Quaternary sediments (Pankova et al. 2010). Hydromorphic saline soils are azonal and occur mostly in lacustrine and riparian habitats. They are often covered with a salt crust, formed as the result of water level fluctuation and intense evaporation.

Regardless of their origin, saline soils support halophytic vegetation consisting of various salt-tolerant and salt-resisting species. Some of them can grow also on soils contaminated with metals and accumulate their ions (hyperaccumulators). As such, they can be used in the phytoremediation processes (Aralova et al. 2009; Toderich et al. 2010). 
Though accumulation and excretion of salts and metals by halophytes were described in details (e.g., Aralova et al. 2009; Sookbirsingh et al. 2010; Flowers and Colmer 2015; Yuan et al. 2016), there are still some problems with the distinction between salts and metals excreted by salt glands (biocrystals) and deposited on plant surface with atmospheric dust (detrital material). In arid and semi-arid zones, atmospheric dust transported at long distances is known to significantly affect soil chemistry (Issanova et al. 2015; Zhu 2016; Opp et al. 2017). Consequently, it will also influence the chemical composition of plant biomass, either remaining in/on the wax layer covering plant surface or entering leaves via stomatal openings. So far, several methods have been suggested to distinguish between plant excretions and dust deposition, including pretreatment methods (washed versus unwashed samples) and measurement methods (Yuan et al. 2016). Yet, they are either questionable or time-consuming and complicated, which makes them unsuitable for monitoring analyses.

Therefore, we suggest using a fractionation of metals in soils (according to a sequential extraction procedure established by the EU Community Bureau of Reference, see Table 1) as an indirect method to assess potential atmospheric dust input to metal content in plant biomass (Pueyo et al. 2008). Assuming that metals present in the soil as fractions bound with sulfates and organic matter and as a residual fraction are plant-inaccessible, their

Table 1 The EU Community Bureau of Reference (CBR) sequential extraction scheme for metals/metalloids and rare earth element (REEs) fractionation in the soil.

\begin{tabular}{|c|c|c|}
\hline Fraction & Phases & Procedure \\
\hline $\mathrm{F} 1$ & $\begin{array}{l}\text { Mobile/exchangeable } \\
\text { elements; bound with } \\
\text { carbonates }\end{array}$ & $\begin{array}{l}0.5 \mathrm{~g} \text { soil with } 20 \mathrm{~mL} 0.1 \mathrm{M} \\
\mathrm{NH}_{4} \mathrm{OAc} \text {, shake for } 16 \mathrm{~h} \\
\text { in room temperature }\end{array}$ \\
\hline $\mathrm{F} 2$ & Fe-Mn oxide bound & $\begin{array}{c}20 \mathrm{~mL} 0.1 \mathrm{M} \mathrm{NH}_{2} \mathrm{OH} \mathrm{HCl} \\
\left(\mathrm{pH}=2 \text { with } \mathrm{HNO}_{3}\right) \\
\text { shake for } 16 \mathrm{~h} \text { in room } \\
\text { temperature }\end{array}$ \\
\hline F3 & $\begin{array}{l}\text { Sulfide bound and } \\
\text { organic matter }\end{array}$ & $\begin{array}{l}30 \% \mathrm{H}_{2} \mathrm{O}_{2}, 5 \mathrm{~mL} \text {, room } \\
\text { temperature, } 1 \mathrm{~h} \text {, followed } \\
\text { by } 1 \mathrm{~h} \text { in } 85{ }^{\circ} \mathrm{C}, \\
\text { occasionally shake; add } \\
5 \mathrm{~mL} 30 \% \mathrm{H}_{2} \mathrm{O}_{2}, 85^{\circ} \mathrm{C}, \\
1 \mathrm{~h} \text {; add } 1 \mathrm{M} \mathrm{NH}_{4} \mathrm{OAc} \\
\left(\mathrm{pH} 2 \text { with } \mathrm{HNO}_{3}\right) 25 \mathrm{~mL}, \\
\text { room temperature, and } \\
\text { shake for } 16 \mathrm{~h}\end{array}$ \\
\hline $\mathrm{F} 4$ & Residues fraction & $\mathrm{HNO}_{3}+\mathrm{HCl}$ \\
\hline
\end{tabular}

occurrence in plant biomass can be viewed as a result of atmospheric deposition. In the presented research, we studied the abundance of selected metals/metalloids and rare earth elements (REEs) and their fractions in soil and compare it with results obtained for plant biomass to assess the potential influence of atmospheric deposition in the desert regions of Kazakhstan.

\section{Materials and methods}

\section{Study area}

In the area of $2.72 \mathrm{Mln} \mathrm{km}^{2}$, Kazakhstan is the biggest state in Central Asia. Its landscape is dominated by deserts, semi-deserts, and steppes, covering $80 \%$ of the total area. (Pachikin et al. 2014). Our research was conducted in southeastern and southwestern parts of Kazakhstan in two zones representing soil distribution: (1) desert zone with brown and gray-brown soils; (2) dry and desert-steppe zone with chestnut (kastanozems) soils and in the surroundings of rivers Illi and SyrDarya and Lake Balkhash, where developed azonal hydromorphic soils.

The desert zone with brown and gray-brown soils covers up to $44 \%$ of the territory of Kazakhstan, mostly in the southern latitudinal bioclimatic zones, e.g., in undrained lowlands around the Caspian Sea and the Aral Lake, on the Ustyurt Plateau, in the Balkash-Alakol depression, and on sloping foothills of the mountain ranges of Tien-Shan, Zhongariya, Altay, and SaurTarbaagatay. Dry and desert-steppe zone with chestnut soils occupies more than $30 \%$ of the territory of Kazakhstan and can be characterized by a variety of automorphic soils with alkaline, calcareous, and saline-salt complexes in the soil profiles, which are usually weakly developed. Such soils are typical for the Pre-Ural and Trans-Ural Plateaus, some parts of Caspian lowlands, plain of Irtish, and foothills of Altay and Tarbagatai Mountains (Saparov 2014). Saline marshes develop mostly in riverine deltas, alluvial plains, and lake depressions covered by semihydromorphic, hydromorphic, and hypersaline soils (solonchaks) or sandy soils formed by the eolian processes (Pankova et al. 2010).

Soil degradation is a serious problem in Kazakhstan. (Saparov 2014; Pachikin et al. 2014) It is estimated that $75 \%$ of the Kazakhstani territory is covered with degraded soils, and $14 \%$ of these soils were classified as heavily degraded. According to Laiskhanov et al. 2016), 
the area of $41 \%$ of Kazakhstani soils is saline. Eleven percent out of them are subject to secondary salinization, mostly due to inappropriate irrigation techniques (Otarov 2014). As agriculture plays an important role in the Kazakhstani economy, irrigation-related secondary salinization causes severe losses of arable soils, estimated at several thousands of hectares per year. Apart from industrial pollution, coming mostly from mines and smelters of various metals (including rare earth elements), secondary salinization is the main challenge of the Kazakhstani environmental policy. Currently, pollution and salinity monitoring are one of the top priorities for Kazakhstani research institutions, especially in the context of food security (Kazakh Ministry Report 2018).

Species used in research

Genus Tamarix (tamarisk, salt cedar) belongs to the Tamaricaceae family, which contains 78 species adapted mostly to dry and saline habitats (Christenhusz and Byng 2016). Since species from the Tamarix genus excrete excess salts as crystals through glandular cells, they can be classified as recretohalophytes (excretive xerohalophytes) (Albert et al. 2000; Breckle 2002). Tamarix species occur in a variety of dry habitats, e.g., on deserts and semi-deserts, saline sandy soils, saline wetlands, and riverine deltas. They are present also in many contaminated sites and were described as accumulators of metals (Manousaki et al. 2008; Toderich et al. 2010; Sookbirsingh et al. 2010; Fawzy et al. 2006). Therefore, Tamarix species can be used as bioindicators in the monitoring of soil contamination with metals, especially in arid areas, where high soil salinity limits the number of potential bioindicators.

\section{Sampling}

Both soil and plant samples were taken in June 2012 from 13 sites: two sites in the desert zone (9G and $11 \mathrm{G}$ ), three sites in the desert-steppe zone (4G, 5G, and 6G), six sites in the alluvial plains $(1 \mathrm{G}, 2 \mathrm{G}, 3 \mathrm{G}, 7 \mathrm{G}, 8 \mathrm{G}$, and $10 \mathrm{G})$, and two sites in the lake depression (12G and $13 \mathrm{G}$ ) (Fig. 1). For the purpose of further analyses, we divided sampled soils into two categories, namely

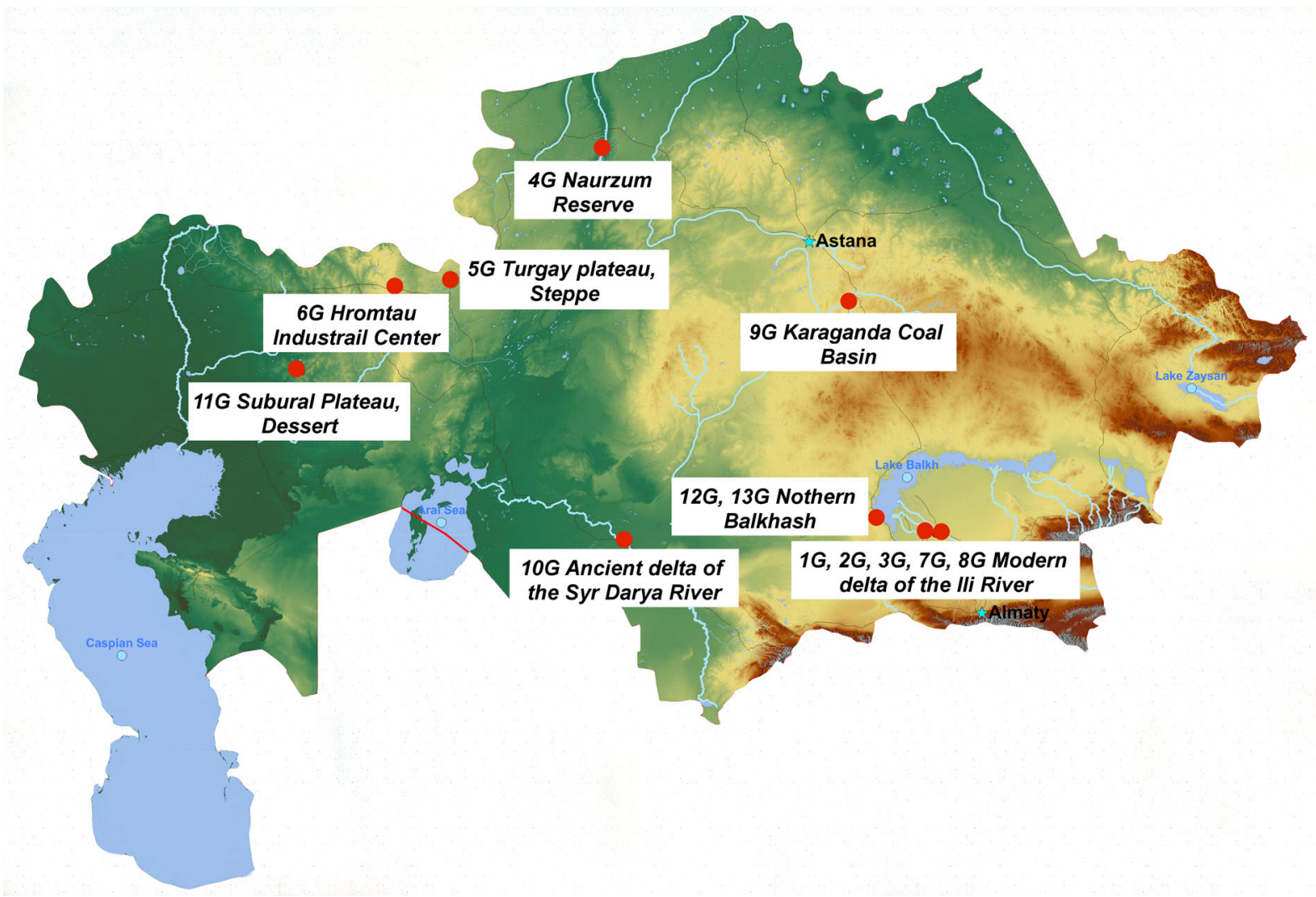

Fig. 1 Location of sampling sites in the territory of the Republic of Kazakhstan. 
automorphic soils (in our case gray-brown and chestnuts soils developed in desert and steppe zone) and hydromorphic soils (in our case soils formed in river deltas and around lakes).

From each sampling site, we collected a mixed soil sample comprising five subsamples (approximately $50 \mathrm{~g}$ in total) from the top $20 \mathrm{~cm}$ of the soil in the immediate vicinity of Tamarix spp. shrubs. Additionally, a mixed sample of 3-10 branches of an individual Tamarix spp. shrub (approximately $20 \mathrm{~g}$ of leaves and branches combined) was collected at each sampling site. Soil and plant samples were stored in paper bags and transported to the Laboratory of Biogeochemistry and Environmental Protection at the Biological and Chemical Research Centre of the University of Warsaw.

\section{Laboratory analyses}

Collected soils were air-dried, ground, and sieved through a 1-mm sieve to remove stones, roots, and other large particles. Soil $\mathrm{pH}$ was measured in a 1:1 soil/water and 1:1 soil/1M KCl solvents. Soil total carbon (TC), total nitrogen (TN), and total organic carbon (TOC) (after removal carbonates using 10\% $\mathrm{HCl}$ were determined using CHN Flash 2000 Elementary Analyzer). The soil organic matter (SOM) was calculated as follows $\mathrm{SOM}=1.724 \mathrm{TOC}$ (Ruehlmann and Körschens 2009). Electrical conductivity (EC) was measured with Hach HQ40d device in water extract (soil:water ratio 1:5) and recalculated to the electrical conductivity of soil saturated extract $(\mathrm{ECe})$ at $25^{\circ} \mathrm{C}[\mathrm{dS} / \mathrm{m}]$ (Shirokova et al. 2000). For the assessment of total concentrations of metals/metalloids $\mathrm{Be}, \mathrm{Cd}, \mathrm{Co}, \mathrm{Cr}, \mathrm{Cs}, \mathrm{Cu}$, $\mathrm{La}, \mathrm{Mn}, \mathrm{Mo}, \mathrm{Ni}, \mathrm{Pb}, \mathrm{Se}, \mathrm{Sn}, \mathrm{Tl}$, and $\mathrm{Zn}$ ) and REEs $(\mathrm{Ce}, \mathrm{Nd}, \mathrm{Pr}$, and $\mathrm{Zr}$ ) in soil samples, a three-stagemodified procedure proposed by the EU Community Bureau of Reference was used (Table 1) (Pueyo et al. 2008). The measurements were performed by Inductively Coupled Plasma Mass Spectrometer ICP MS (Perkin Elmer NexION 300D).

For the assessment of total concentrations of metals/metalloids (Be, Cd, Co, Cr, Cs, Cu, La, Mn, $\mathrm{Mo}, \mathrm{Ni}, \mathrm{Pb}, \mathrm{Se}, \mathrm{Sn}, \mathrm{Tl}$, and $\mathrm{Zn}$ ) and REEs (Ce, Nd, $\mathrm{Pr}$, and $\mathrm{Zr}$ ) in plant samples, plants were air-dried and ground to a fine powder with the centrifugation mill. Subsamples of $0.1 \mathrm{~g}$ of plant material were decomposed in $6 \mathrm{~mL}$ of $65 \% \mathrm{HNO}_{3}$ (Ultranal) in a Berghof SpeedWave 4 microwave digestion system. Concentrations of elements in question were measured with Perkin Elmer NexION 300D inductively coupled plasma mass spectrometer.

All reagents used were of analytical reagent grade or better. The accuracy of the elemental analysis was checked by the determination of metals/metalloids and REEs in the standard reference materials of soil (light sandy soil BCR142R, Sigma Aldrich) and leafs using Polish Virginia Tobacco Leaves ICINCT (LGC standards).

\section{Statistical analyses}

As the parameters studied failed to meet the assumptions of parametric tests (normal distribution and/or equal variances), non-parametric tests were used (KruskalWallis test for comparisons between soil types and Spearman correlation coefficient to estimate relations between soil and plant chemistry). For a better estimation of links between metals/metalloids and REEs content in soils and in plants, bioaccumulation factor (BF) for each element was calculated as a ratio of the content of a certain element in the plant to its content in soil (US E.P.A 2007). All statistical analyses were carried out in STATISTICA 13.

\section{Results}

General characteristics of the studied soils

Detailed chemical characteristics of the studied soils are presented in Table 2. In the case of salinity and electrical conductivity, both automorphic and hydromorphic soils were most differentiated. Hydromorphic soils tended to have higher values of these parameters, with salinity between 566 and $8900 \mathrm{mg} / \mathrm{L}$ and electrical conductivity between 8.47 and $272.66 \mathrm{dS} / \mathrm{m}$. For hydromorphic soils, the highest values of salinity and ECe were recorded in samples from the valley of the Illi River. In comparison, the salinity range of automorphic soils was between 63 and $3640 \mathrm{mg} / \mathrm{L}$ and electrical conductivity between $1.92-432 \mathrm{dS} / \mathrm{m}$. However, the observed differences between soil types were not statistically significant. In case of automorphic soils, the highest values of salinityrelated parameters were recorded in soils sampled from the industrial areas of Karaganda $(3640 \mathrm{mg} / \mathrm{L}$ and $432.02 \mathrm{dS} / \mathrm{m}$ ) and Chromtau Industrial Centre (2130 mg/L and $30.19 \mathrm{dS} / \mathrm{m})$. A pH of the studied soils 


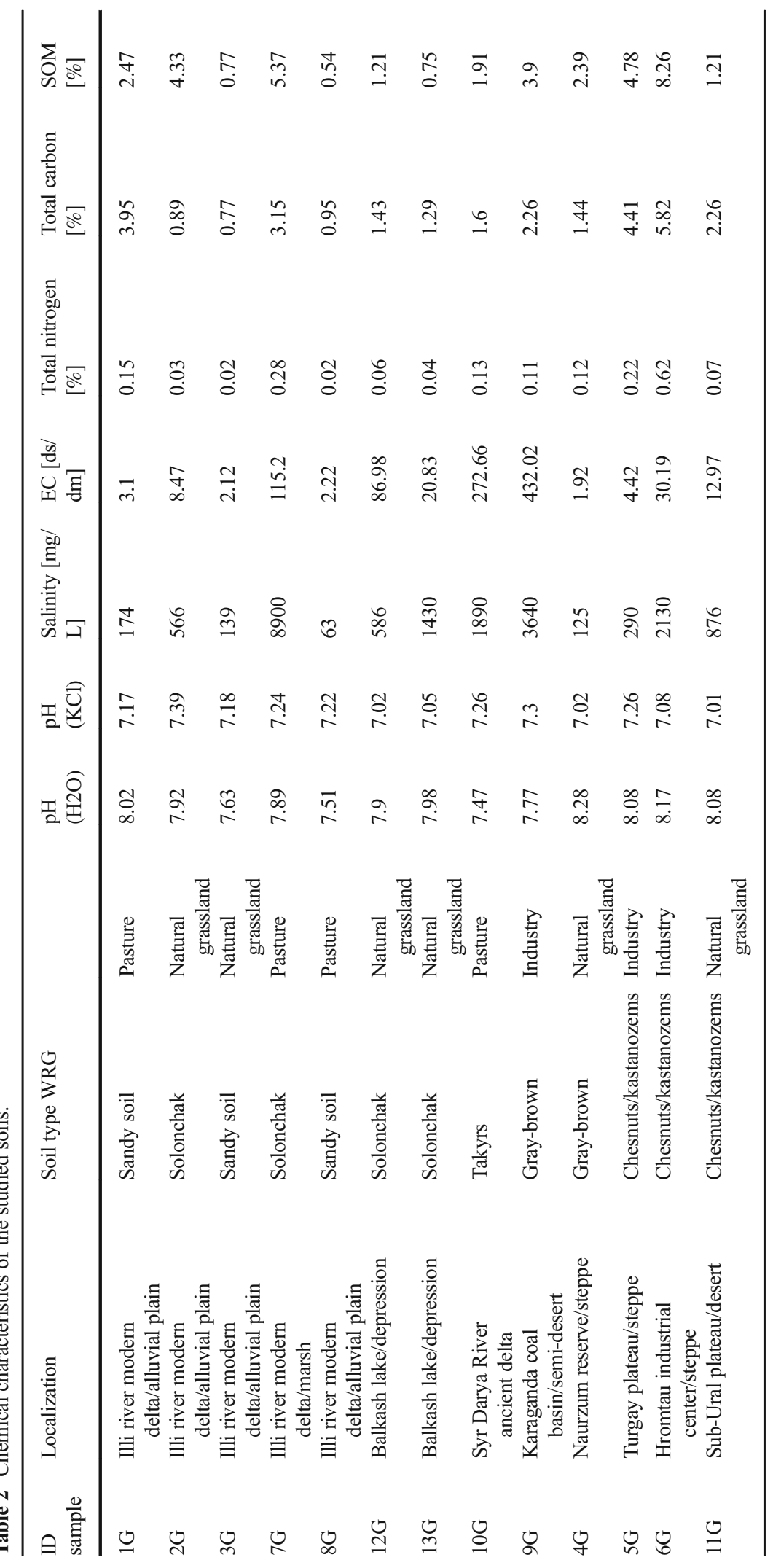


covered very similar ranges - for hydromorphic soils 7.02 to 7.39 and for automorphic soils 7.01 to 7.30.

Hydromorphic soils contained on average lower amounts of soil organic matter, namely between 0.75 and $5.37 \%$ than automorphic soils (from 0.54 to $8.26 \%$ ). The same trends could be observed for other parameters related to organic matter ( $\mathrm{TC}$ and $\mathrm{TN}$ ), yet again, the observed differences had no statistical significance.

Similarly to salinity-related parameters, the content of metals/metalloids and REEs in soil samples was very differentiated and corresponded with sampled location, i.e., soils from industrial areas and from floodplains of the Illi river contained higher levels of these elements than the other samples (Table 3). The content of several elements $(\mathrm{Cd}, \mathrm{Co}$, $\mathrm{Cr}, \mathrm{Cu}, \mathrm{Se}$, and $\mathrm{Zn}$ ) in soils was significantly correlated with the amount of total organic carbon with $r^{2}$ values between 0.60 and 0.69 and $p<0.05$.

Relationship between total content of the studied elements in soils and in plant material

As in soils, the content of metals/metalloids and REEs in plant material was also very differentiated and usually lower than in corresponding soil samples. Positive correlations between content of metal/ metalloid or REEs in soil and in corresponding plant sample were recorded for $\mathrm{Zn}\left(\underline{r}^{2}=0.58, p=0.0375\right)$, $\mathrm{Pb}\left(\mathrm{r}^{2}=0.63, p=0.0203\right)$, and $\mathrm{Ni}\left(r^{2}=0.78, p=\right.$ 0.0017). For better assessment of this relation, $\mathrm{BF}$ factors were calculated (Fig. 2).

The highest $\mathrm{BF}$ values were recorded for $\mathrm{Cd}$ and covered a range of 0.52 to 98.17 , with a median value of 8.08 .

$\mathrm{BF}$ values for $\mathrm{Cu}, \mathrm{Mn}, \mathrm{Mo}$, and $\mathrm{Zn}$ were comparable and covered a range between 0.02 and 1.60 (with one higher value for $\mathrm{Mn}$ ), with a median value between 0.22 and 0.40 . The median value for Se was similar (1.84), yet BF values were scattered from 0.24 to 8.36 . BFs of other metals and REEs were in a range between 0.001 $(\mathrm{Ce})$ and $0.239(\mathrm{Cs})$ with medians in between $0.014(\mathrm{Ce})$ and $0.056(\mathrm{Be})$.

Sequential extraction of metals/metalloids and REEs from soils

Percentages of different fractions of selected metals and REEs in the studied soils are presented in Fig. 3.
Most of the studied elements prevail in soils as fractions F4 (alumino-silicates, between 78.5 and 98.7\%) and F3 (metalorganic compounds, between 1.0 and $12.3 \%$ ), with the total amount of F1 and F2 fractions between 0.3 to $6.2 \%$. However, there are two exceptions of this general rule - $\mathrm{Cd}$ with the domination of $\mathrm{F} 4$ and F3 fractions (consequently, 50.6 and $17.7 \%$ ), yet the much higher share of F1 and F2 fractions $(31.2 \%$ in total), and $\mathrm{Mn}$, characterized by a completely different pattern. In the case of Mn, $90.5 \%$ of this metal occurred in the soil as F1 (31.2\%) and F2 (59.2\%) fractions, with only $9.5 \%$ of fractions F3 and F4. Excluding the abovementioned exceptions, in the case of REEs (Ce, $\mathrm{Pr}$, and $\mathrm{Nd}$ ), the total percentage of $\mathrm{F} 1$ and $\mathrm{F} 2$ fractions remained under $1 \%$, for toxic metals $(\mathrm{Cr}$ and $\mathrm{Pb})$ it remained below $10 \%$, and for microelements $(\mathrm{Cu}, \mathrm{Zn}$, $\mathrm{Mo}$, and $\mathrm{Co}$ ) it was in a range from 6 to $20 \%$. General trends observed showed that BFs are positively correlated with percentages of F1 fraction $\left(r^{2}=0.69, p=\right.$ 0.0192 ) and negatively with percentages of $\mathrm{F} 4$ fraction $\left(r^{2}=-0.62, p=0.0402\right)$.

\section{Discussion}

Though the salinity of the soils and their content of metals/metalloids and REEs were very differentiated and covered a wide range of values, some general trends were visible. While automorphic soils, especially arenosols, developed on sandy dunes were the least saline and contained the lowest amounts of metals/ metalloids and REEs, hydromorphic soils from river valleys showed the highest values of the measured parameters. The latter type of the soils is formed under the constant influence of either surface or ground waters, which combined with intense evaporation in arid zones, results in enhanced salinization. Moreover, hydromorphic soils are relatively rich in organic matter, which effectively binds metal ions. Recent studies on saline hydro- and automorphic soils in Kazakhstan showed that saline meadow soils contained significantly higher amounts of metals than saline chestnut soils. Thus, highlighting the influence of soil organic matter on metal dynamics in saline soils (Sharipow et al. 2017). According to the research of Pankova and Konyushkova (2013), who studied soil salinization in the context of landscape, pedological, and climatic factors, saline hydromorphic soils will be subject to further salinization due to advancing climate warming (intense evaporation 


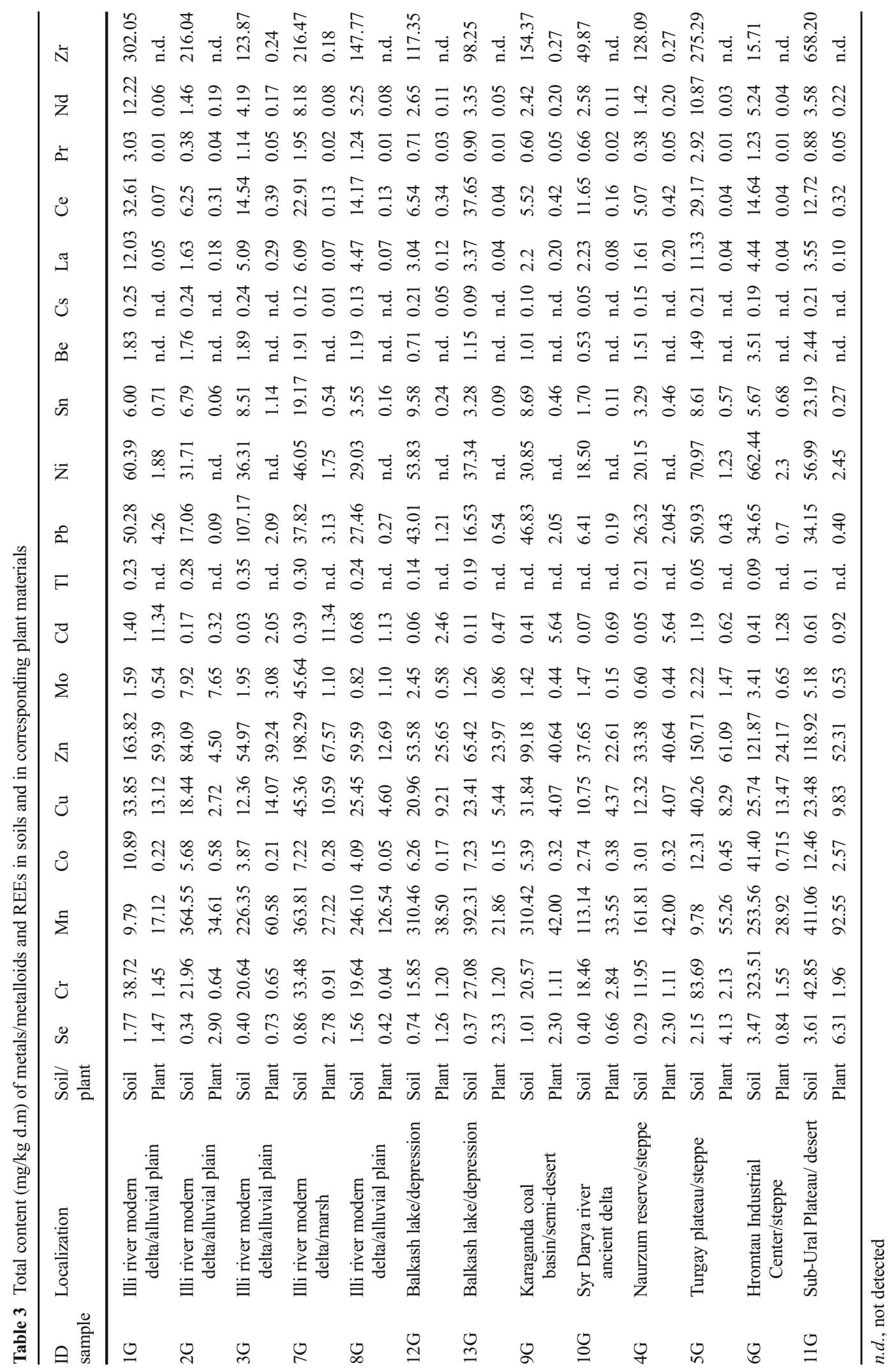



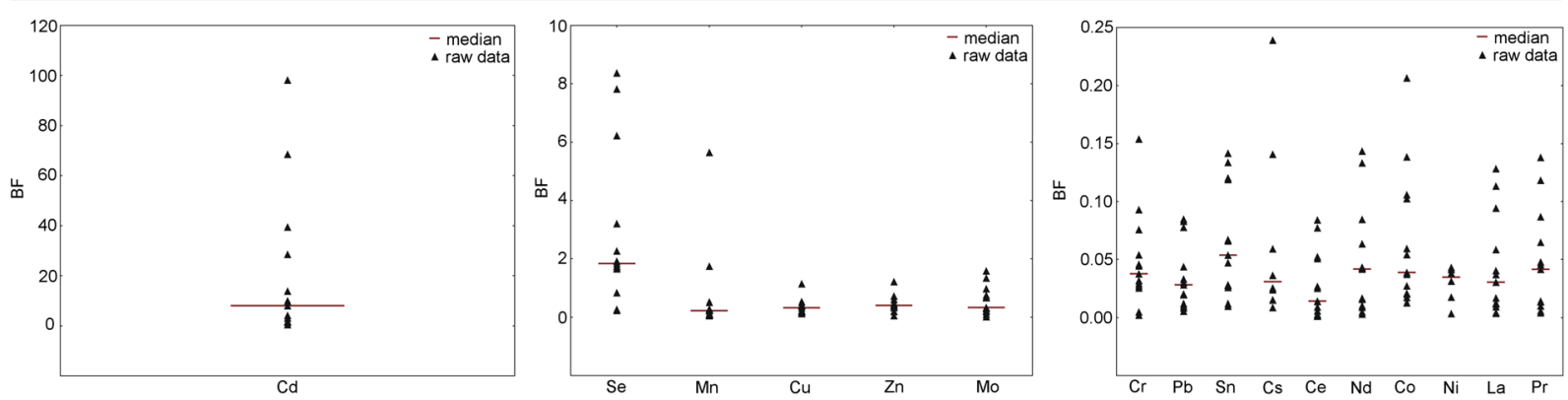

Fig. 2 Bioaccumulation factors (BFs) for the studied metals/metalloids and REEs in plant material (Tamarix spp.). Due to great differences in $\mathrm{BF}$ values, different ranges of Y-axis were used

leading to increased salinity of ground waters) and agricultural irrigation (extra influx of salts with waters used for irrigation) (Pankova et al. 2010; Pankova and Konyushkova 2013). Moreover, waters used for irrigation in the Central Asia region are very often enriched in various pollutants such as pesticide remaining from fields or toxic metals from mines and smelters. Our observations confirmed the noticeable influence of industrial activities on metals/metalloids and REEs content in soils. However, the increased values of these elements did not necessarily lead to higher bioaccumulation factors. Presumably, due to the domination of plant-inaccessible fractions F3 and F4 in soils. This is also a probable cause of such a small number of significant correlations between the content of elements in soil and in corresponding plant material. Regarding legal Kazakhstani limits of the most frequently monitored metals, they were exceeded in all our samples in the case of $\mathrm{Cu}$ (all results over $3 \mathrm{mg} / \mathrm{kg}$ ) and $\mathrm{Zn}$ (all results over $23 \mathrm{mg} / \mathrm{kg}$ ). In the case of $\mathrm{Cd}$, one third of our

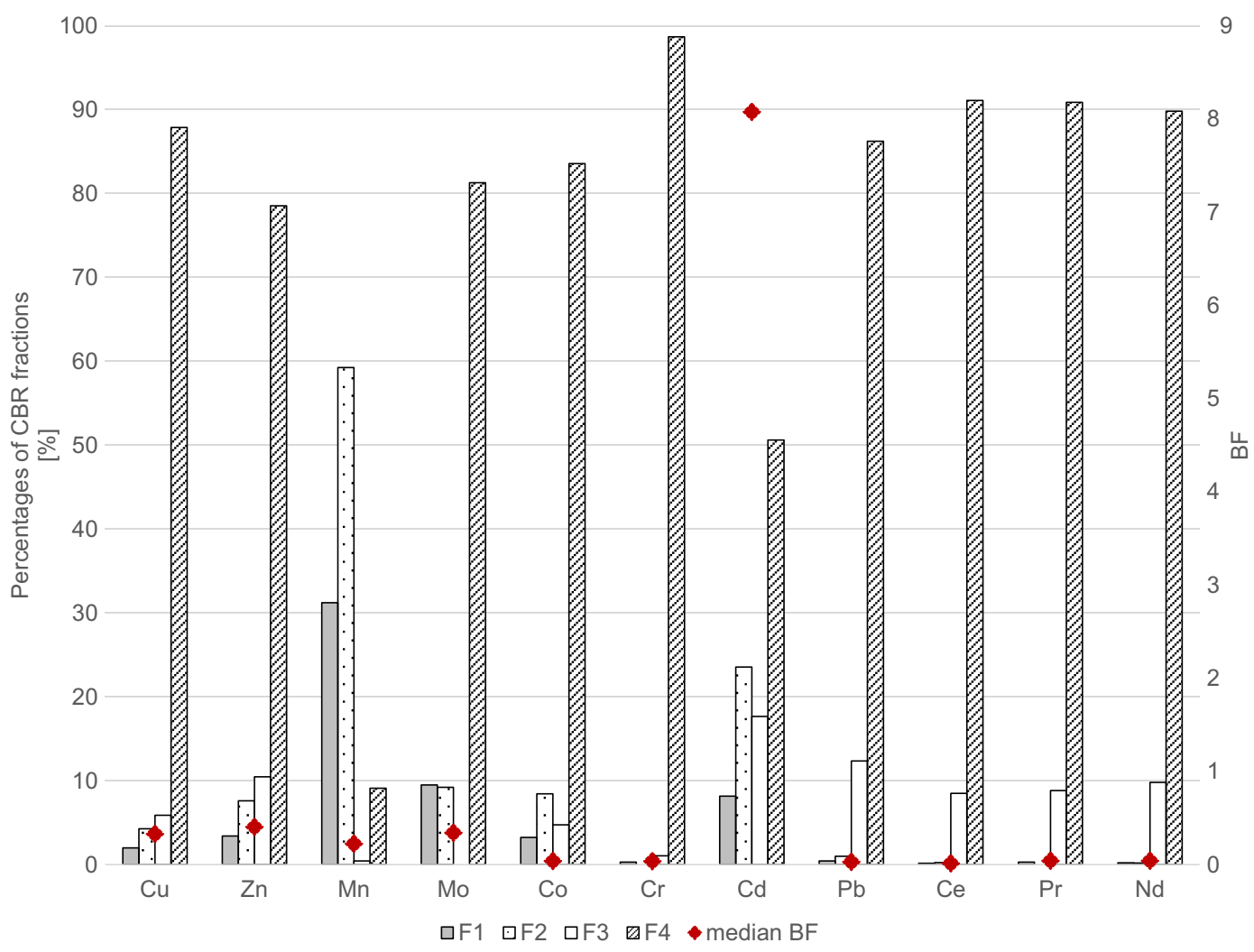

Fig. 3 Percentages of different fractions of selected metals and REEs in the studied soils as obtained by the CBR sequential extraction procedure 
samples exceeded the value of $0.5 \mathrm{mg} / \mathrm{kg}$ (only one of these samples was from the industrial area), and in case of $\mathrm{Pb}$, half of our samples exceeded the value of $32 \mathrm{mg} / \mathrm{kg}$ (including all samples from industrial areas).

Content and composition of salts and metals/ metalloids and REEs in soils of arid regions depends on weathering and pedogenic processes that result from the geological and geomorphological characteristic of a given area and are under influence of hydrological and climatic factors. Currently, a major role is played as well by human influences, namely industrial activities, and, especially in arid regions, irrigated agriculture (Kitamura et al. 2006; Satybaldiyev et al. 2015; Laiskhanov et al. 2016; Hamidov et al. 2016). Apart from these factors, many studies performed in arid zones highlighted the importance of eolian dust in shaping soil chemistry, even at a long distance from its original source (Issanova et al. 2015; Zhang et al. 2016; Opp et al. 2017). Dust transported from more or less natural ecosystems, such as the West and Central Asian deserts are well-mixed, with background values of industryrelated contaminants and only minor seasonal variations in its composition (Wu et al. 2009, 2015). However, if eolian dust originates in contaminated areas, it contains significant amounts of inorganic and organic pollutants, which is especially well visible in the areas of the driedout bed of the Aral Lake (Aral-Kum desert). Dust, sand, and salt storms occurring in natural and anthropogenic deserts of Central Asia transport large amounts of deflated material over long distances, significantly affecting agricultural areas as well as human health (Issanova et al. 2015; Zhang et al. 2016; Opp et al. 2017). As the influence of eolian dust (apart from irrigation procedures) was described in the valley of the Illi River (Sommer et al. 2013; Laiskhanov et al. 2016), we believe that increased values of REEs recorded by us in arenosols from this area might result from atmospheric deposition.

Various Tamarix species, known as recretohalophytes (excretive xerohalophytes) (Albert et al. 2000; Breckle 2002), are able to accumulate metals from saline and polluted soils (Manousaki et al. 2008; Matsuo et al. 2013). Toderich et al. (2010) recorded remarkably high values of $\mathrm{Fe}, \mathrm{Ti}, \mathrm{Zn}, \mathrm{Cu}, \mathrm{Sr}$, and $\mathrm{Co}$ in leaves of Tamarix hipsida growing on saline and contaminated soils of the Central Kyzylkum desert (Uzbekistan) and proposed to describe this species as a hyperaccumulator (Toderich et al. 2010). In comparison to results described by Toderich et al. (2010), content of Mn, Cr, Co, Mo, Ni, and $\mathrm{Be}$ in Tamarix individuals presented in this article was lower, while content of $\mathrm{Cu}, \mathrm{Zn}, \mathrm{Pb}$, and $\mathrm{Cd}$ was higher, with values for $\mathrm{Cd}$ exceeding these given by Toderich even by three orders of magnitude.

These dissimilarities probably result from different pollution sources and pollution profiles for the Central Kyzylkum desert and our study areas. In the case of Cd, high content recorded for plant biomass resulted in extremely high values of BF for this element (up to 98). According to Manousaki et al. (2008), Tamarix smyrnesis growing on saline soils significantly increases absorption of $\mathrm{Cd}$, and, simultaneously, its excretion via salt glands (a detoxification mechanism) (Manousaki et al. 2008).

As in our case, the content of $\mathrm{Cd}$ in soils remained on a reasonably low level (between 0.03 and $1.40 \mathrm{mg} / \mathrm{kg}$ ) and was uncorrelated with BFs; we believe that the accumulation of $\mathrm{Cd}$ in the studied Tamarix individuals was enhanced by eolian deposits on the surface of plants.

In contrast to metals and metalloids, bioaccessibility of rare earth elements (RREs, as defined by (Tyler 2004; Doł gowska and Migaszewski 2013; Srivastava and Kumar 2017), and their influence on plant physiology remains still insufficiently studied. At the same time, their input into the environment is rapidly growing with the development of new technologies. Scientists have described so far several cases of decreased root growth, impaired seed germination, and damaged chlorophyll particles as potential results of REEs accumulation in plant tissues (Li et al. 1998; Tyler 2004; Loell et al. 2011; Doł gowska and Migaszewski 2013; Wiche et al. 2017). In our case, REEs content in soils remained much lower than world averages given by (Kabata-Pendias and Pendias 2001) and over $98 \%$ of the extracted REEs was in form of plant-inaccessible F3 and F4 fractions. Median values of BFs obtained for REEs in our study were between 0.01 and 0.04 and were lower than $\mathrm{BF}$ values recorded at the level of 0.04-0.09 (Migaszewski and Gałuszka 2015). Therefore, we can state, that in our case bioaccessibility of REEs was low and their potential influence on plant development probably negligible.

\section{Conclusions}

- Soils in the studied regions of Kazakhstan can be classified as polluted with $\mathrm{Cu}, \mathrm{Zn}, \mathrm{Cd}$, and $\mathrm{Pb}$, yet in most cases, bioaccumulation factors remained low and plant biomass was uncontaminated as most of 
the studied elements were present in plantinaccessible forms.

- Even if elements were present in plant-accessible forms, we recorded no correlation with their abundance of plant biomass $(\mathrm{Mn})$.

- High accumulation of $\mathrm{Cd}$ in biomass, with approximately $70 \%$ of this element present in soils as plantinaccessible fractions, indicates the impact of $\mathrm{Cd}$ atmospheric deposition.

- Fractionation of metals in soils can be used as an indirect method for indication of potential atmospheric deposition.

Open Access This article is distributed under the terms of the Creative Commons Attribution 4.0 International License (http:// creativecommons.org/licenses/by/4.0/), which permits unrestricted use, distribution, and reproduction in any medium, provided you give appropriate credit to the original author(s) and the source, provide a link to the Creative Commons license, and indicate if changes were made.

Publisher's Note Springer Nature remains neutral with regard to jurisdictional claims in published maps and institutional affiliations.

\section{References}

Albert R, Pfundner G, Hertenberger G, Kastenbauer T, Watzka M (2000) The physiotype approach to understanding halophytes and xerophytes In: S. W. Breckle, B. Schweizer, \& U. Arndt (Eds.), Ergebnisse weltweiter ökologischer Forschung (pp. 69-87). Germany: Verlag Günter Heimbach.

Aralova, D., Shuyskaya, E., Khujanazarov, T., Toderich, K., Taha, F., Oishi, S., Voronin, P., \& Black, C. (2009). Assessment of halophytic vegetation to improve livestock feeding resources on saline desert rangelands. Annales of Geomatics, VII., 5(35), 7-17.

Breckle, S. W. (2002). Salinity, halophytes and salt affected natural ecosystems. In A. Läuchli \& U. Lüttge (Eds.), Salinity: Environment - Plants - Molecules (pp. 53-77). Netherlands: Kluwer Academic.

Christenhusz, M. J. M., \& Byng, J. W. (2016). The number of known plants species in the world and its annual increase. Phytotaxa. Magnolia Press, 261(3), 201-217.

Doł gowska, S., \& Migaszewski, Z. M. (2013). Anomalous concentrations of rare earth elements in the moss-soil system from south-central Poland. Environmental Pollution, 178, $33-40$

Fawzy, E. M., Soltan, M. E., \& Sirry, S. M. (2006). Mobilization of different metals between Tamarix parts and their crystal saltssoil system at the banks of river Nile, Aswan, Egypt. Toxicological and Environmental Chemistry, 88(4), 603-618.
Flowers, T. J., \& Colmer, T. D. (2015). Plant salt tolerance: Adaptations in halophytes. Annals of Botany, 115(3), 327-331.

Hamidov, A., Helming, K., \& Balla, D. (2016). Impact of agricultural land use in Central Asia: a review. Agronomy for Sustainable Development, 36(1), 1-23.

Issanova, G., Abuduwaili, J., Galayeva, O., Semenov, O., \& Bazarbayeva, T. (2015). Aeolian transportation of sand and dust in the Aral Sea region. International Journal of Environmental Science and Technology, 12(10), 3213-3224.

Kabata-Pendias, A., \& Pendias, H. (2001). Trace elements in soils and plants trace elements in soils and plants (3rd ed.). Boca Raton: CRC Press.

Kazakh Ministry Report, (2018). Implementation plan of the Republic of Kazakhstan on the obligations under the Stokholm convention on Persistent Organic Pollutants for 2015 - 2018.

Kitamura, Y., Yano, T., Honna, T., Yamamoto, S., \& Inosako, K. (2006). Causes of farmland salinization and remedial measures in the Aral Sea basin-research on water management to prevent secondary salinization in rice-based cropping system in arid land. Agricultural Water Management, 85(1-2), 1-14.

Laiskhanov, S. U., Otarov, A., Savin, I. Y., Tanirbergenov, S. I., Mamutov, Z. U., Duisekov, S. N., \& Zhogolev, A. (2016). Dynamics of soil salinity in irrigation areas in South Kazakhstan. Polish Journal of Environmental Studies, 25(6), 2469-2476.

Li, F., Shan, X., Zhang, T., \& Zhang, S. (1998). Evaluation of plant availability of rare earth elements in soils by chemical fractionation and multiple regression analysis. Environmental Pollution, 102(2-3), 269-277.

Loell, M., Albrecht, C., \& Felix-Henningsen, P. (2011). Rare earth elements and relation between their potential bioavailability and soil properties, Nidda catchment (Central Germany). Plant and Soil, 349(1-2), 303-317.

Manousaki, E., Kadukova, J., Papadantonakis, N., \& Kalogerakis, N. (2008). Phytoextraction and phytoexcretion of Cd by the leaves of Tamarix smyrnensis growing on contaminated nonsaline and saline soils. Environmental Research, 106(3), 326-332.

Matsuo, N., Oijka, K., Shuyskaya, E., Radjabov, T., Toderich, K., \& Yamanaka, N. (2013). Responses of the carbon and oxygen isotope compositions of desert plants to spatial variation in soil salinity in Central Asia. Ecological Research, 28(5), 717-723.

Migaszewski, Z., \& Gałuszka, A. (2015). The characteristics, occurrence, and geochemical behaviour of rare earth elements in the environment: a review. Critical Reviews in Environmental Science and Technology, 45, 429-471.

Opp, C., Groll, M., Aslanov, L., Lotz, T., Vereshagina, N., et al. (2017). Aeolian dust deposition in the southern Aral Sea region (Uzbekistan): Ground-based monitoring results from the LUCA project. Quaternary International, 429, 86-99.

Otarov, A. (2014). Concentration of heavy metals in irrigated soils in Southern Kazakhstan. In L. Mueller, A. Saparov, \& G. Lischeid (Eds.), Novel measurement and assessment tools for monitoring and management of land and water resources in agricultural landscapes of Central Asia. Environmental Science and Engineering (pp. 519-533). Switzerland: Springer International Publishing.

Pachikin, K., Erokhina, O., \& Funakawa, S. (2014). Soils of Kazakhstan, their distribution and mapping. In L. Mueller, 
A. Saparov, \& G. Lischeid (Eds.), Novel measurement and assessment tools for monitoring and management of land and water resources in agricultural landscapes of Central Asia. Environmental Science and Engineering (pp. 519533). Switzerland: Springer International Publishing.

Pankova, E. I., \& Konyushkova, M. V. (2013). Climate and soil salinity in the deserts of Central Asia. Eurasian Soil Science, 46(7), 771-727.

Pankova, Y., Konyushkova, M., \& Luo, G. (2010). Effect of climate on soil salinity in subboreal deserts of Asia. Russian Agricultural Sciences, 39(5-6), 464- 467.

Pueyo, M., Mateu, J., Rigol, A., Vidal, M., Lopez-Sanchez, J. F., \& Rauret, G. (2008). Use of the modified BCR three-step sequential extraction procedure for the study of trace element dynamics in contaminated soils. Environmental Pollution, 152(2), 330-341.

Ruehlmann, J., \& Körschens, M. (2009). Calculating the effect of soil organic matter concentration on soil bulk density. Soil Science Society of America Journal, 73(3), 876.

Saparov, A. (2014). Soil recources of the Republic of Kazakhstan: current status, problems and solutions. In L. Mueller, A. Saparov, \& G. Lischeid (Eds.), Novel measurement and assessment tools for monitoring and management of land and water resources in agricultural landscapes of Central Asia. Environmental Science and Engineering (pp. 61-73). Switzerland: Springer International Publishing.

Satybaldiyev, B., Tuovinen, H., Uralbekov, B., Lehto, J., \& Burkitbayev, M. (2015). Heavy metals and natural radionuclides in the water of Syr Darya River, Kazakhstan. In B. J. Merkel \& A. Arab (Eds.), Uranium - past and future challenges (pp. 155-156). Switzerland: Springer International Publishing.

Sharipow, K., Kirgizbayeva, A., Omirzakova, B., Batyrbayeva, A., \& Toktabayeva, A. (2017). Dependence of microelements and heavy metals content in soils of some regions of Kazakhstan on the organic structure and soil type. Journal of Chemical Technology and Metallurgy, 52(5), 962-968.

Shirokova, Y., Forkutsa, I., \& Sharafutdinova, N. (2000). Use of electrical conductivity instead of soluble salts for soil salinity monitoring in Central Asia. Irrigation and Drainage Systems, 14, 199-205.

Sommer, R., Glazirina, M., Yuldashev, T., Otarov, A., Ibrayeva, M., Martynova, L., Bekenov, M., Kholov, B., Ibragimov, N., Kobilov, R., Karaev, S., Sultonov, M., Khasanova, F., Esanbekov, M., Mavlyanov, D., Isaev, S., Abdurahimov, S.,
Ikramov, R., Shezdyukova, L., \& de Pauw, E. (2013). Impact of climate change on wheat productivity in Central Asia. Agriculture, Ecosystems and Environment, 178, 78-99.

Sookbirsingh, R., Castillo, K., Gill, T. E., Chianelli, R., et al. (2010). Salt separation processes in the saltcedar Tamarix ramosissima (Ledeb.). Communications in Soil Science and Plant Analysis, 41(10), 1271-1281.

Srivastava, V., \& Kumar, R. (2017). Soil salinity: a serious environmental issue and plant growth promoting bacteria as one of the tools for its alleviation. Saudi Journal of Biological Sciences, 22, 123-131.

Toderich, K., Shuyskaya, E. V., Khujanazarov, T., Ismail, S., \& Kawabata, Y. (2010). The structural and functional characteristics of asiatic desert halophytes for phytostabilization of polluted sites. In M. Ashraf, M. Ozturk, \& M. S. A. Ahmad (Eds.), Plant adaptaion and phytoremediation (pp. 245275). London: Springer Dordrecht Heidelberg.

Tyler, G. (2004). Rare earth elements in soil and plant systems - a review. Plant and Soil, 267(1), 191-206.

US E.P.A, (2007). Framework for metals risk assessment framework for metals risk assessment, EPA 120/R-07/001. https://www.epa.gov/sites/production/files/2013-09 /documents/metals-risk-assessment-final.pdf.

Wiche, O., Zertani, V., Hentschel, W., Achtziger, R., Midula, P., et al. (2017). Germanium and rare earth elements in topsoil and soil-grown plants on different land use types in the mining area of Freiberg (Germany). Journal of Geochemical Exploration, 175, 120-129.

Wu, G., Xu, B., Zhang, C., Gao, S., \& Yao, T. (2009). Geochemistry of dust aerosol over the Eastern Pamirs. Geochimica et Cosmochimica Acta, 73, 977-989.

Wu, G., Zhang, C., Zhang, X., Xu, T., Yana, N., \& Gao, S. (2015). The environmental implications for dust in high-alpine snow and ice cores in Asian mountains. Global and Planetary Change, 124, 22-29.

Yuan, F., Leng, B., \& Wang, B. (2016). Progress in studying salt secretion from the salt glands in recretohalophytes: how do plants secrete salt? Frontiers in Plant Science, 7, 1-12.

Zhang, R., Ma, X., Wang, M., Lv, H., \& Zhu, C. (2016). Effects of salinity and water stress on the physiological and ecological processes and plasticity of Tamarix ramosissima seedlings. Acta Ecologica Sinica, 36(6), 433-441.

Zhu, B. Q. (2016). Atmospheric significance of aeolian salts in the sandy deserts of northwestern China. Solid Earth, 7(1), 191-203. 